\title{
Interacting Flooding and Competition Negatively Affect Growth of Riparian Species Dominating a Reservoir Shoreline
}

\author{
Yu-Han Chen ${ }^{1}$, Xin-Sheng Sun ${ }^{1}$, Yuan Cui ${ }^{1}$, Na Zhuo ${ }^{1}$, Guan-Wen Wei ${ }^{1}$, Fang-Li Luo ${ }^{1,2, *}$ and \\ Ming-Xiang Zhang ${ }^{1,2, *}$
}

1 School of Ecology and Nature Conservation, Beijing Forestry University, Beijing 100083, China; cchenyuhan@163.com (Y.-H.C.); sxs15801425810@163.com (X.-S.S.); cuiyuanmail@163.com (Y.C.); veronicamg1@163.com (N.Z.); kathywgw@163.com (G.-W.W.)

2 The Key Laboratory of Ecological Protection in the Yellow River Basin of National Forestry and Grassland Administration, Beijing 100083, China

* Correspondence: ecoluofangli@bjfu.edu.cn (F.-L.L.); zhangmingxiang@bjfu.edu.cn (M.-X.Z.); Tel.: +86-10-62336293 (F.-L.L.)

Citation: Chen, Y.-H.; Sun, X.-S.; Cui, Y.; Zhuo, N.; Wei, G.-W.; Luo, F.-L.; Zhang, M.-X. Interacting Flooding and Competition Negatively Affect Growth of Riparian Species Dominating a Reservoir Shoreline. Water 2021, 13, 1471.

https://doi.org/10.3390/w13111471

Academic Editor: Eva Papastergiadou

Received: 2 March 2021

Accepted: 19 May 2021

Published: 24 May 2021

Publisher's Note: MDPI stays neutral with regard to jurisdictional claims in published maps and institutional affiliations.

Copyright: (C) 2021 by the authors Licensee MDPI, Basel, Switzerland. This article is an open access article distributed under the terms and conditions of the Creative Commons Attribution (CC BY) license (https:/ / creativecommons.org/licenses/by/ $4.0 /)$.

\begin{abstract}
Plant-plant interactions change in response to environmental conditions, and riparian species are commonly influenced by flooding. This study tested whether flooding affects the intraspecific and interspecific competition of two riparian species and whether such effects depend on the topographic positions where plants have established. Seeds of the riparian species Polygonum hydropiper were collected from both low and high positions within the shoreline of the Three Gorges Reservoir. Groups of P. hydropiper seedlings from each position were either grown alone (i.e., without competition), with another group of $P$. hydropiper seedlings (i.e., intraspecific competition), or with a group of seedlings of the companion species Xanthium sibiricum (i.e., interspecific competition). Each group comprised six replicates. In total, 288 plants of $P$. hydropiper and 84 plants of X. sibiricum were selected for the experiment. Seedlings were subjected to control and flooding treatments for 60 days. Irrespective of competition type (i.e., intra- or interspecific), both flooding and competition negatively affected the growth and/or photosynthetic capacities of $P$. hydropiper. Flooding only interacted with competition to explain total biomass. Flooding reduced total biomass in a larger proportion in the absence of competition, and, to a lesser extent, with intraspecific competition, compared to interspecific competition. However, such interaction effects were independent of the positions where the seeds that originated from the plants were collected from. Interspecific competition significantly decreased the chlorophyll content and photosynthetic efficiency of plants, while intraspecific competition did not. In general, plants from lower positions had higher total chlorophyll content than plants from higher positions. These results suggest that flooding may regulate the population dynamics of P. hydropiper by altering its competitive interactions.
\end{abstract}

Keywords: hydrofluctuation zone; interspecific competition; intraspecific competition; waterlogging; wetland plant

\section{Introduction}

Flooding greatly affects both the survival and growth of riparian plants [1-3]. The intensity of the impact that flooding has on riparian plants varies greatly with topographic position across the valley cross-section [4-6]. Plants growing at sites of lower elevation are usually more exposed to flooding than plants at a higher elevation. Previous studies have shown that in riparian zones, species richness, composition, and diversity of plant communities vary greatly across the valley cross-section [4,7].

As plant-plant interactions change depending on the stress they are exposed to, interactions among riparian species may vary greatly with the flooding conditions of riparian areas $[8,9]$. Moreover, the stress gradient hypothesis (SGH) indicates that plant-plant interactions shift toward a reduction in competition in response to increasing levels of 
environmental stress [10-12]. Therefore, flooding may affect both intraspecific and interspecific competition of riparian species. Research has shown that the effects of flooding on competitive interactions among wetland species are species specific, and in response, competitive intensity may either increase, decrease, or not change at all $[13,14]$. For a specific species, in response to the selection pressures imposed by natural flooding, intraspecific differentiation may emerge among individuals from different habitats. Consequently, different ecotypes with different phenotypic plasticities may emerge [15,16]. Several studies have shown that phenotypic variation within species can be as pronounced as that between species [17-19]. If these ecotypes responded differently to flooding, then flooding may alter their intraspecific and/or interspecific competitive abilities. In contrast, if their responses to flooding are similar, then flooding will not affect their competitive ability. However, few studies have tested whether the effects of flooding on the competitive ability of riparian plants vary with the position across the valley cross-section where the plants are distributed.

After the completion of the Three Gorges Dam, the riparian corridor of the Yangtze River Basin between Jiangjin County in Chongqing City and Zigui County in Yichang City has partially become the shoreline of the Three Gorges Reservoir (TGR) [20,21]. As a result of water-level management operations (since 2009), the water level of the TGR fluctuates repeatedly from $145 \mathrm{~m}$ above sea level (a.s.l.) in September to $175 \mathrm{~m}$ a.s.l. in November and then gradually back to $145 \mathrm{~m}$ a.s.l. until the following May. The water level is maintained at $145 \mathrm{~m}$ a.s.l. from May to September. This results in the formation of a hydrofluctuation belt (HFB) in the shoreline with a total area of $350 \mathrm{~km}^{2}$ and $30 \mathrm{~m}$ variation in topographic elevation [20,22]. This variation implies a large difference in flooding intensity for plants distributed at different positions within the HFB. In particular, plants at a lower position could be submerged for up to six months and with a water level of up to $30 \mathrm{~m}[22,23]$. After 10 years of water-level fluctuations, species numbers, as well as the height and density of plant communities, decreased remarkably with a decreasing position within the HFB $[4,5,24]$. Correspondingly, individuals of riparian species that are distributed at different positions within the HFB may show different responses to flooding.

Annual herbs are an important life form in most riparian zones and occupy a large proportion of plants within the HFB of the TGR $[5,24]$. After long-term submergence, as the original vegetation degrades, these could become dominant species. Polygonum hydropiper is such an annual herb $[25,26]$, with a natural distribution at both low and high positions within the HFB. This species has a high tolerance to partial submergence and exhibits phenotypic plasticity of both leaves and adventitious roots in response to flooding [25]. P. hydropiper often coexists with the herbaceous plant Xanthium sibiricum [25].

In most temperate regions, global climate change increases the frequency of intense precipitation events [27]. An increase in flooding events may impose strong selection pressures on riparian species and affect both their intraspecific and/or interspecific competition levels. This may lead to changes in their population and community structures. Moreover, a number of studies provided support for the SGH in water-constrained plant communities, such as semiarid steppes [28,29]. However, the results of other studies were inconsistent with the SGH $[30,31]$. To test the SGH simultaneously for both intraspecific and interspecific competition under flooded conditions, seeds of $P$. hydropiper were collected from both low and high positions within the HFB of the TGR. The naturally occurring X. sibiricum was chosen as an interspecific competitor. Specifically, the following two hypotheses were tested: (1) the intraspecific and interspecific competitive ability of $P$. hydropiper decreases in flooded conditions; (2) plants from low and high positions respond differently to the interaction of flooding and competition. The intensity of interspecific or intraspecific competition was evaluated by measuring the growth of $P$. hydropiper plants in treatments with or without $X$. sibiricum conducted in a greenhouse. 


\section{Material and Methods}

\subsection{Plant Species}

Polygonum hydropiper L. (Polygonaceae) is an annual herb [32] that prefers moist conditions, e.g., lakeshores, riverbanks, or wet depressions. It is native to Asia and also widely distributed throughout temperate Australia, Europe, and North America. Its branched stems can grow to a length of $40-70 \mathrm{~cm}$. This species normally flowers from May to September and produces viable seeds from June to October. In wetlands, it also produces overwintering belowground rhizomes [33]. P. hydropiper is naturally distributed throughout the HFB, all along the TGR, where it either forms large monospecific stands or coexists with Xanthium sibiricum Patrin [25]. As X. sibiricum occupies a similar ecological niche to $P$. hydropiper, it was selected as the competitive species of $P$. hydropiper in this experiment.

\subsection{Plant Material}

Seeds of $P$. hydropiper were collected from populations of both low and high positions at the following three different sites within the HFB of the TGR in September 2016: Beibei District $\left(106^{\circ} 26^{\prime} 58^{\prime \prime}\right.$ E, $29^{\circ} 40^{\prime} 60^{\prime \prime} \mathrm{N} ; 106^{\circ} 26^{\prime} 54^{\prime \prime}$ E, $\left.29^{\circ} 41^{\prime} 02^{\prime \prime} \mathrm{N}\right)$, Wushan County $\left(109^{\circ} 54^{\prime} 27^{\prime \prime} \mathrm{E}, 31^{\circ} 07^{\prime} 31^{\prime \prime} \mathrm{N} ; 109^{\circ} 54^{\prime} 29^{\prime \prime} \mathrm{E}, 31^{\circ} 07^{\prime} 29^{\prime \prime} \mathrm{N}\right)$, and Badong County $\left(110^{\circ} 18^{\prime} 16^{\prime \prime} \mathrm{E}\right.$, $31^{\circ} 12^{\prime} 19^{\prime \prime} \mathrm{N} ; 110^{\circ} 18^{\prime} 19^{\prime \prime} \mathrm{E}, 31^{\circ} 12^{\prime} 20^{\prime \prime} \mathrm{N}$ ) in Chongqing, China. Sample sites were at least $25 \mathrm{~km}$ apart. The difference in elevation between low- (150-155 $\mathrm{m}$ a.s.l.) and high-position (165-175 $\mathrm{m}$ a.s.l.) populations ranged from 10 to $25 \mathrm{~m}$. For these six populations, the collected seeds of each population were mixed. X. sibiricum plants were also cultivated from seeds that were collected at a low position within the HFB of the TGR.

On 5 June 2018, 100 plump seeds from each population of $P$. hydropiper were selected and germinated on Petri dishes using river sand as substrate. Germination was conducted in the greenhouse. On 3 July, 210 seeds of X. sibiricum were selected and germinated in seedling trays, also using river sand as substrate. During germination, tap water was added to maintain the required moisture of the river sand. On 19 July, when seedlings of both species had grown to ca. $6 \mathrm{~cm}$, they were transplanted into plastic pots $(11 \mathrm{~cm}$ upper diameter, $8 \mathrm{~cm}$ bottom diameter, and $10 \mathrm{~cm}$ depth) filled with a mixture of soil, peat, and river sand (3:1:1, v:v:v). The soil mixture contained the following nutrients: $1.51 \pm 0.03 \mathrm{mg}$ total $\mathrm{N} \mathrm{g}^{-1}$, and $1.46 \pm 0.03 \mathrm{mg}$ total $\mathrm{P} \mathrm{g}^{-1}$. After recovery for a week, the experiment started on 27 July 2018.

\subsection{Evaluating the Vertical Seed Dispersal Potential}

To assess the degree of interconnection between low- and high-position populations, the potential for seed dispersal between low and high positions ("vertical seed dispersal distance" hereafter) was estimated as the seed floating time in water $\times$ water-level rise rate. A total of 100 plump seeds were randomly selected from each of the six populations to estimate the seed floating time. The seeds of each population were added to a beaker $(500 \mathrm{~mL}$ ) filled with $400 \mathrm{~mL}$ of tap water (resulting in a total of six beakers). The water was gently stirred, and the time from the onset of the sinking of the first seed until the last seed had touched the bottom was recorded as the seed floating time. The water-level rise rate was calculated based on the daily water level during the impoundment of the TGR, using the means of the fastest three-day rise rates each year (Supplementary Table S1). Data on the daily water level were obtained from the publicly available national water and rain information network for 2009-2018 at http:/ / xxfb.mwr.cn/sq_djdh.html (accessed on 5 August 2020).

\subsection{Experimental Design}

Plants of $P$. hydropiper that had been germinated from seeds of low- and high-position populations, taken from the three different sites, were included. Forty-eight plants were selected from each population, which yielded a total of 288 plants. Eighty-four plants of $X$. sibiricum of uniform size were selected for the experiment. The experiment used a factorial design with two water levels (i.e., control and flooding) and three types of competition (i.e., 
without competition, intraspecific competition, and interspecific competition), resulting in a total of eight treatments for plants both from low and high positions (Figure 1). Each treatment was replicated six times. In the control treatment (i.e., no flooding), plants were watered daily and in the flooding treatment plants were waterlogged to the soil surface, $\sim 10 \mathrm{~cm}$ from the bottom of the pot. In the treatment without competition, one plant of $P$. hydropiper or X. sibiricum was grown in the center of the pot; in the treatment with intraspecific competition, two P. hydropiper plants were grown together in one pot; in the treatment with interspecific competition, one plant of $P$. hydropiper and one plant of $X$. sibiricum were grown together in one pot. For treatments with competition, the distances between plants and between plants and the pot edge were 5 and $3 \mathrm{~cm}$, respectively. The plant density in treatments with competition was set according to the natural distribution of these two species within the HFB of the TGR, identified by a field survey.

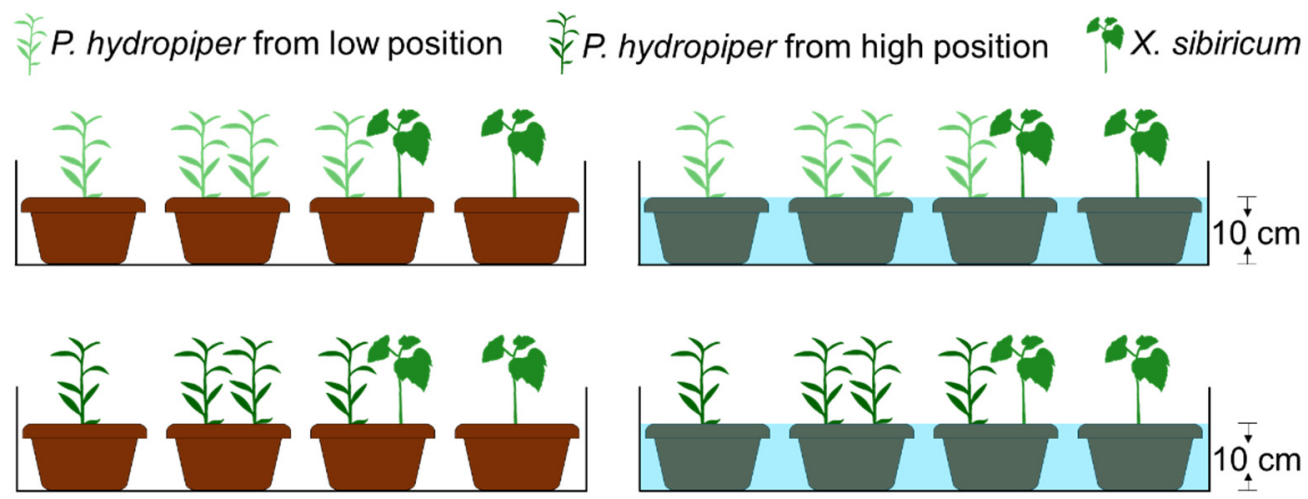

Figure 1. Schematic representation of the experimental design. The experiment included two water levels (i.e., control and flooding), three types of competition (i.e., without, intraspecific, and interspecific), and two positions (i.e., low and high) at the hydrofluctuation belt of the shoreline of the Three Gorges Reservoir. This schema was replicated six times for each of the three sites. In the experiment without competition, one plant of P. hydropiper or X. sibiricum was grown in the center of the pot; in the experiment with intraspecific competition, two $P$. hydropiper plants were grown together in one pot; in the experiment with interspecific competition, one plant of P. hydropiper and one plant of $X$. sibiricum were grown together in one pot.

The experiment lasted for 60 days from 27 July to 24 September 2018. The photosynthetically active radiation, measured at the plant level and at noon, ranged between 800 and $1800 \mu \mathrm{mol}$ photons $\mathrm{m}^{-2} \mathrm{~s}^{-1}$ during the experiment (Li-250A photometer, $\mathrm{Li}-\mathrm{Cor}$ Biosciences, Lincoln, NE, USA). The air temperature in the greenhouse was set to $30-35^{\circ} \mathrm{C}$, and the relative air humidity was $60 \%$ on average at noon. For the flooding treatment, tap water was used and added to the containers to compensate for water loss caused by evapotranspiration.

\subsection{Total Chlorophyll Content and Chlorophyll a Fluorescence Measurements}

Total chlorophyll contents of the youngest, fully expanded leaves of $P$. hydropiper were estimated by using a SPAD-502 (Konica Minolta, Tokyo, Japan). Chlorophyll a fluorescence of $P$. hydropiper was measured on the same leaves between 08:00 and 12:00 by using a portable modulated fluorimeter (PAM-2500, Heinz Walz, Effeltrich, Germany). To determine the maximal $(\mathrm{Fm})$ and minimal fluorescence intensity $(\mathrm{Fo})$, leaves were darkadapted for $30 \mathrm{~min}$ using leaf clips. The intensity and duration of saturation pulses were set to $3500 \mu \mathrm{mol} \mathrm{m}{ }^{-2} \mathrm{~s}^{-1}$ and $1 \mathrm{~s}$, respectively. Thereafter, the maximal $\left(\mathrm{Fm}^{\prime}\right)$ and steady-state fluorescence intensity $(\mathrm{Fs})$ of light-adapted leaves were determined after illumination with $800 \mu \mathrm{mol} \mathrm{m} \mathrm{m}^{-2} \mathrm{~s}^{-1}$ for $4 \mathrm{~min}$. The same intensity and duration of the applied saturation pulse were used as before. The maximal quantum yield of PSII (Fv/Fm) was calculated as $\mathrm{Fv} / \mathrm{Fm}=(\mathrm{Fm}-\mathrm{Fo}) / \mathrm{Fm}$ [34]. The effective quantum yield of PSII was calculated as 
$\Delta \mathrm{F} / \mathrm{Fm}^{\prime}=\left(\mathrm{Fm}^{\prime}-\mathrm{Fs}\right) / \mathrm{Fm}^{\prime}$. Non-photochemical energy quenching (NPQ) in PSII was calculated as $\mathrm{NPQ}=\left(\mathrm{Fm}-\mathrm{Fm}^{\prime}\right) / \mathrm{Fm}^{\prime}$.

\subsection{Growth Measurements}

Plant height of P. hydropiper was measured as the distance from the soil surface to the top of the plant at the end of the experiment. After measuring their height, plants of both P. hydropiper and X. sibiricum were harvested and divided into leaves, stems, and roots. The leaves of each plant were scanned, and the total leaf area was determined by ImageJ (version 1.6.0, National Institutes of Health, Bethesda, MD, USA). Plant tissues were oven-dried at $80^{\circ} \mathrm{C}$ for at least $72 \mathrm{~h}$ to obtain their constant dry mass.

\subsection{Statistical Analyses}

Before analyses, in the treatments with intraspecific competition, data of each variable were divided by the number of plants initially grown in each pot so that the data were scaled to the per-unit plant level. Then, data were assessed for normality and homogeneity of variance. To increase both normality and homogeneity of variance, data for leaf biomass, stem biomass, root biomass, and total leaf area were transformed logarithmically; data for specific leaf area were sine-function transformed prior to analyses. To test the effects of flooding, competition, and position on growth and photosynthetic variables, linear mixed-effect models were conducted using the lme function in the package nlme [35] in R 4.0.4 (R Foundation for Statistical Computing, Vienna, Austria) [36]. In this model, flooding, competition, and position were treated as fixed factors, and the site was treated as a random factor. The significance of random effects, fixed effects, and their interactions was assessed with ANOVA tests. The Student's $t$ test was used to test the differences of total biomass between control and flooding treatments with different competition types, and the Tukey's HSD post hoc test was used to test the differences of total biomass among treatments in control or flooding conditions.

\section{Results}

The floating times of seeds from low and high positions were $10.8 \pm 0.4 \mathrm{~h}$ and $12.0 \pm 0.6 \mathrm{~h}$, respectively. The water level rise in the TGR was $1.1-3.2 \mathrm{~m} \mathrm{day}^{-1}$ from 2009 to 2018 (Supplementary Table S1). The potential vertical dispersal distances of seeds from low and high positions were $0.9 \pm 0.1 \mathrm{~m}$ and $1.0 \pm 0.1 \mathrm{~m}$, respectively. This potential dispersal distance was rather short compared with the 10-25 $\mathrm{m}$ vertical difference between low and high positions. Therefore, the seeds of these plants could hardly disperse between low and high positions with a rising water level.

Flooding significantly decreased leaf biomass, stem biomass, root biomass, total biomass, total leaf area, plant height, chlorophyll content, and effective quantum yield of photosystem II in P. hydropiper when exposed to light $\left(\Delta \mathrm{F} / \mathrm{Fm}^{\prime}\right)$ (Table 1; Figure $\left.2 \mathrm{~A}-\mathrm{H}\right)$; however, it significantly increased NPQ in photosystem II (Table 1; Figure 2I). Both interspecific and intraspecific competition significantly decreased leaf biomass, stem biomass, root biomass, total biomass, total leaf area, and plant height (Table 1; Figure 3A-F). Interspecific competition significantly decreased chlorophyll content and $\triangle \mathrm{F} / \mathrm{Fm}^{\prime}$ but increased NPQ; however, intraspecific competition did not significantly affect these variables (Table 1; Figure 3G-I). Irrespective of competition type, plants from low positions had higher total chlorophyll content than those from high positions (Table $1 ; F=11.79, p<0.001$ ). Interspecific competition also significantly decreased the biomass of X. sibiricum (Supplementary Table S2; Supplementary Figure S1). 
Table 1. Effects of site, flooding, competition, and position on growth and photosynthetic variables of P. hydropiper.

\begin{tabular}{|c|c|c|c|c|c|c|c|c|}
\hline & $\begin{array}{l}\text { Site } \\
\text { (S) }\end{array}$ & $\begin{array}{l}\text { Flooding } \\
\text { (F) }\end{array}$ & $\begin{array}{c}\text { Competition } \\
\text { (C) }\end{array}$ & $\begin{array}{l}\text { Position } \\
\text { (P) }\end{array}$ & $\mathbf{F} \times \mathbf{C}$ & $\mathbf{F} \times \mathbf{P}$ & $\mathbf{C} \times \mathbf{P}$ & $\mathbf{F} \times \mathbf{C} \times \mathbf{P}$ \\
\hline Leaf biomass & $24.09 * * *$ & $26.82 * * *$ & $9.59 * * *$ & 1.58 & 2.18 & 0.04 & 1.69 & 0.64 \\
\hline Stem biomass & $24.21 * * *$ & $16.25^{* * *}$ & $4.33 *$ & 0.89 & 2.35 & 0.05 & 1.90 & 0.49 \\
\hline Root biomass & $24.11 * * *$ & $6.45 *$ & $14.19 * * *$ & 0.30 & 0.58 & 0.21 & 1.52 & 0.42 \\
\hline Total biomass & $21.99 * * *$ & $23.39 * * *$ & $10.24 * * *$ & 0.44 & 3.27 * & 0.10 & 1.20 & 0.85 \\
\hline Total leaf area & $18.68 * * *$ & $17.61 * * *$ & $11.01 * * *$ & 0.52 & 2.12 & 0.18 & 2.59 & 0.78 \\
\hline SLA & 1.45 & 0.09 & 0.53 & 3.29 & 1.53 & 0.18 & 2.11 & 2.34 \\
\hline Plant height & $47.98 * * *$ & $6.72 *$ & $6.72 * *$ & 1.80 & 2.39 & 0.36 & 1.22 & 0.70 \\
\hline Chl content & 1.69 & $12.58 * * *$ & $6.48^{* *}$ & $11.79 * * *$ & 2.30 & 2.35 & 0.78 & 0.06 \\
\hline $\mathrm{Fv} / \mathrm{Fm}$ & $16.44^{* * *}$ & 0.48 & 1.12 & 0.33 & 0.89 & 1.37 & 1.40 & 0.54 \\
\hline$\Delta \mathrm{F} / \mathrm{Fm}^{\prime}$ & $9.17 * *$ & $26.41 * * *$ & $5.98 * *$ & 1.61 & 0.29 & 1.57 & 0.41 & 0.69 \\
\hline NPQ & $<0.01$ & $23.06^{* * *}$ & $3.48 *$ & 0.71 & 0.87 & 0.86 & 0.60 & 0.34 \\
\hline
\end{tabular}

The values are likelihood ratios for effects of $S$ and $F$ values for effects of other factors. The symbols indicate significance levels ${ }^{* * *} p<0.001$, ${ }^{* *} p<0.01,{ }^{*} p<0.05$, and no symbol $p \geq 0.1$ ). SLA: specific leaf area. For growth variables, the degree of freedom is 1,177 for effects of $\mathrm{F}, \mathrm{P}$, and $\mathrm{F} \times \mathrm{P}$, and it is 2177 for effects of $\mathrm{C}, \mathrm{F} \times \mathrm{C}, \mathrm{C} \times \mathrm{P}$, and $\mathrm{F} \times \mathrm{C} \times \mathrm{P}$; for photosynthetic parameters, the degree of freedom is 1130 for effects of $\mathrm{F}, \mathrm{P}$, and $\mathrm{F} \times \mathrm{P}$, and is 2130 for effects of $\mathrm{C}, \mathrm{F} \times \mathrm{C}, \mathrm{C} \times \mathrm{P}$, and $\mathrm{F} \times \mathrm{C} \times \mathrm{P}$. Significant values $(p<0.1)$ are formatted in bold.
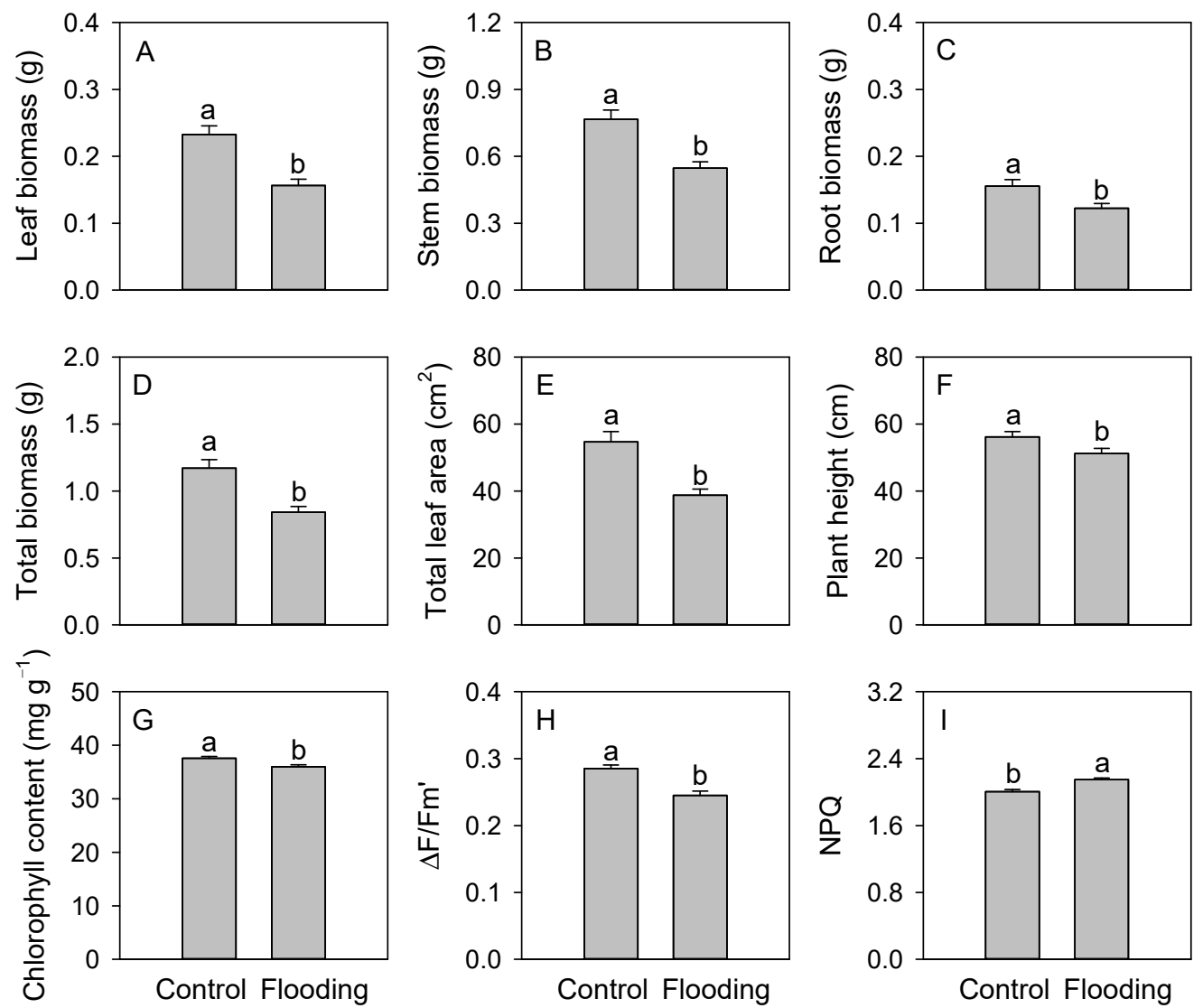

Figure 2. Leaf biomass (A), stem biomass (B), root biomass (C), total biomass (D), total leaf area (E), plant height $(\mathbf{F})$, total chlorophyll content $(\mathrm{G})$, effective quantum yield in the light $\left(\Delta \mathrm{F} / \mathrm{Fm}^{\prime}, \mathbf{H}\right)$, and non-photochemical energy quenching (NPQ, I) of P. hydropiper under control and flooding treatments. Data are mean values (+s.e., $n=6)$. Different letters indicate significant differences $(p<0.05)$. 

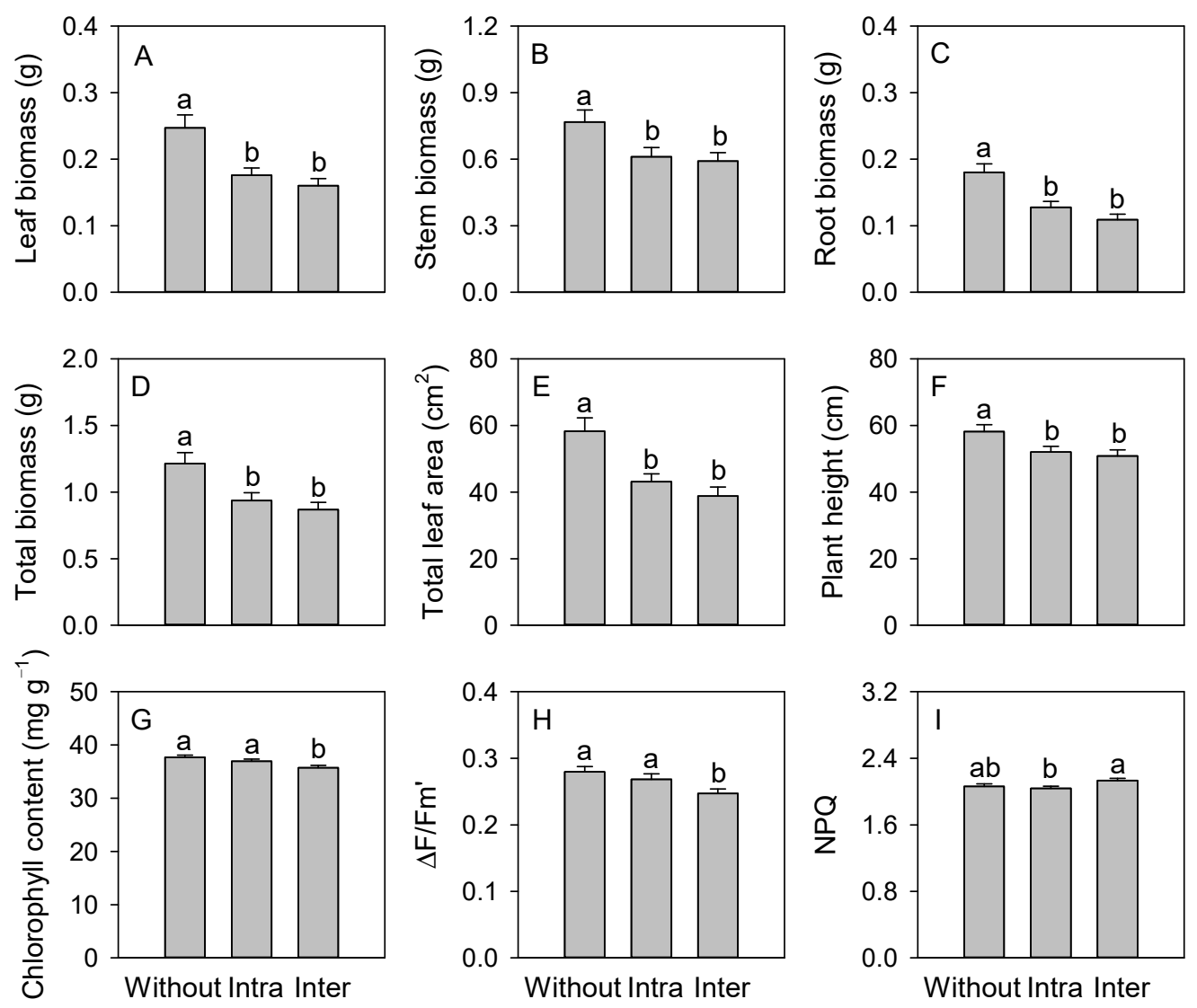

Figure 3. Leaf biomass (A), stem biomass (B), root biomass (C), total biomass (D), total leaf area (E), plant height $(\mathbf{F})$, total chlorophyll content $(\mathbf{G}), \Delta \mathrm{F} / \mathrm{Fm}^{\prime}(\mathbf{H})$, and NPQ (I) of P. hydropiper under treatments with intraspecific competition (i.e., Intra), with interspecific competition (i.e., Inter), or without competition (i.e., Without). Data are mean values (+s.e., $n=6)$. Different letters indicate significant differences $(p<0.05)$.

The interactive effects of flooding and competition exerted significant effects on total biomass (Table 1). In the control conditions, the total biomass of the treatment without competition was significantly higher than that of treatments with competition. No significant differences were found between treatments with and without competition in the flooding conditions (Figure 4). Flooding significantly decreased the total biomass of plants without competition and, in a smaller proportion, with intraspecific competition, but did not significantly affect plants with interspecific competition (Figure 4). These results suggest that the negative effects of competition, particularly of interspecific competition, on total biomass were not significantly intensified with flooding. 


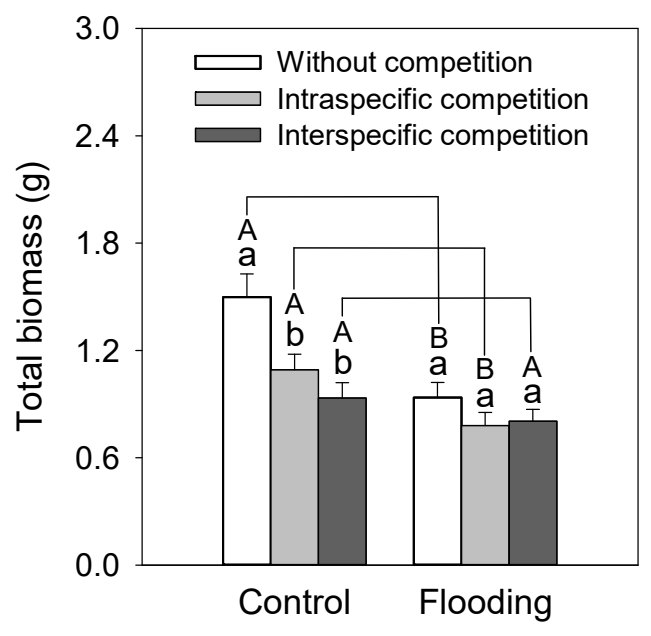

Figure 4. Total biomass of $P$. hydropiper under control and flooding treatments without competition, with intraspecific competition, or with interspecific competition. Data are mean values $(+$ s.e., $n=6)$. Different lowercase letters indicate significant differences among treatments in control or flooding conditions, whereas different uppercase letters indicate significant differences between control and flooding treatments with different competition types $(p<0.05)$.

\section{Discussion}

Consistent with previous reports, both flooding and competition significantly inhibited the growth of P. hydropiper [37-39]. Compared with the control treatment, flooding did not intensify the negative effects of competition on plant growth (i.e., significant flooding-bycompetition effects were found for total biomass; see Figure 4). Flooding decreased the total biomass more intensively in the treatment without competition than for both types of competition. In stressed conditions, the trade-off between stress tolerance and competitive ability is important for the coexistence of species and for plant-plant interactions [40,41]. If plants have to allocate more energy to stress tolerance, their competitive ability may decrease [10-12]. In this study, P. hydropiper showed high tolerance to flooding and retained $\sim 60 \%$ of its total biomass after 60 days of waterlogging (Figure 2). Interspecific competition significantly decreased photochemical efficiency but increased photoprotective energy dissipation of P. hydropiper [42]. Moreover, the flooding treatment might change the tissue responses of species and lead to niche differentiation, which may ultimately decrease their competitive ability $[43,44]$. Therefore, these results corroborate the first hypothesis that the intensity of both types of competition on the total biomass of P. hydropiper decreases in flooded conditions compared with the control.

The interactive effects of flooding and competition on plant growth did not vary with the topographic positions the plants originated from, which is inconsistent with the second hypothesis. Within the HFB of the TGR, a number of studies have shown differences in flooding intensities between low and high positions, e.g., flooding depth and frequency $[20,45]$. Other studies have found that flooding imposed different selection pressure on the plasticity of $P$. hydropiper at different positions in water fluctuation zones along lakeshores or riverbanks $[33,46]$. Furthermore, the interaction of local condition and position had significant effects on growth and reproduction traits of P. hydropiper in the TGR, suggesting that the effects of position varied greatly among different local conditions [47].

Previous studies have emphasized the necessity for assessing both intra- and interspecific relationships when studying the influence of abiotic conditions on plant-plant interactions [14,43]. In this study, intra- and interspecific competition did not have different effects on the growth of P. hydropiper in both control and flooded conditions. Several studies have predicted different effects between intra- and interspecific competition, which may vary among species types [37,48]. However, most of these studies focused on coexisting species in terrestrial plant communities [37,49]. As the limiting resources differ between ter- 
restrial and wetland plants, the link between intra- and interspecific competition may also change [14]. Interestingly, interspecific competition significant decreased the chlorophyll $a$ content and photosynthetic efficiency while increasing the capacity of nonphotochemical energy quenching; however, intraspecific competition did not. Similarly, a recent study has also found a decreased chlorophyll $a$ content in a forest species subjected to interspecific competition [49]. The results suggest that $P$. hydropiper was able to maintain or adjust its photosynthetic capacity in response to both types of competition.

Irrespective of competition, position significantly affected the total chlorophyll content of $P$. hydropiper, which matches the conclusion of a previous field study [47]. Plants from the low position had higher total chlorophyll content compared with plants from the high position (Table $1 ; p<0.001$ ). A recent study has found that, in response to flooding, plants of this species from the low position had a higher specific leaf area than plants from the high position [46]. Waterlogging and partial submergence often cause oxygen deficiencies in both roots and shoots $[50,51]$. Photosynthetic and metabolic processes therefore could be severely inhibited under flooding, thus impeding plant growth [50]. As adaptations to flooding, high total chlorophyll content and specific leaf area could benefit gas exchange of plants from a lower position $[52,53]$.

\section{Conclusions}

Irrespective of type (i.e., intra- or interspecific), both flooding and competition negatively affected the growth and/or photosynthetic capacities of P. hydropiper. Flooding did not intensify the negative effects of competition on the total biomass of plants. These interaction effects were independent of positions within the hydrofluctuation belt (HFB) of the Three Gorges Reservoir where plants were distributed. Although intra- or interspecific competition had similar effects on growth variables, they showed different effects on chlorophyll content and photosynthetic efficiency. Therefore, flooding may regulate the population dynamics of $P$. hydropiper by altering its competitive interaction. Plant-plant interactions play an important role in structuring riparian plant communities $[39,43,54]$. In this study, the interspecific relationship was only considered via the competition between $P$. hydropiper and one of its concomitant species. Whether the relationship between riparian species varies with changes of species number and identity still remains unclear and needs to be further studied.

Supplementary Materials: The following are available online at https:/ / www.mdpi.com/article / 10.3390/w13111471/s1, Figure S1: Leaf biomass (A), stem biomass (B), root biomass (C), and total biomass (D) of X. sibiricum under treatments with interspecific competition (i.e., Inter), or without competition (i.e., Without), Table S1: Fastest 3-day period of water-level rise at the Three Gorges Reservoir from 2009 to 2018, Table S2: Effects of flooding, interspecific competition, and position on growth of Xanthium sibiricum.

Author Contributions: Data curation, Y.-H.C., N.Z. and G.-W.W.; formal analysis, Y.-H.C.; funding acquisition, F.-L.L. and M.-X.Z.; methodology, Y.-H.C.; supervision, F.-L.L.; writing-original draft preparation, X.-S.S.; writing-review and editing, F.-L.L., Y.-H.C., Y.C. and M.-X.Z. All authors have read and agreed to the published version of the manuscript.

Funding: This study was supported by the National Key R\&D Program of China (2017YFC0505903) and the National Natural Science Foundation of China (31670428, 32071525, and 41771547).

Institutional Review Board Statement: Not applicable.

Informed Consent Statement: Not applicable.

Data Availability Statement: All data generated or analyzed in this study are included in this published article and its supplementary information files.

Acknowledgments: We thank Jian-Nan Chen, Jia-Rui Yan, Yu-Die Zhao, Yu-Fan Chen, and Yi-Fu Luo for their assistance during plant sampling and sample analyses.

Conflicts of Interest: The authors declare no conflict of interest. 


\section{References}

1. Loreti, E.; van Veen, H.; Perata, P. Plant responses to flooding stress. Curr. Opin. Plant Biol. 2016, 33, 64-71. [CrossRef]

2. Voesenek, L.A.C.J.; Bailey-Serres, J. Flood adaptive traits and processes: An overview. New Phytol. 2015, 206, 57-73. [CrossRef]

3. Winkel, A.; Visser, E.J.W.; Colmer, T.D.; Brodersen, K.P.; Voesenek, L.A.C.J.; Sand-Jensen, K.; Pedersen, O. Leaf gas films, underwater photosynthesis and plant species distributions in a flood gradient. Plant Cell Environ. 2016, 39, 1537-1548. [CrossRef]

4. Liu, M.Z.; Liu, Y.Y.; Zeng, B.; Niu, H.G.; Liu, S.P.; Pan, X.J.; Xie, J.J.; Shi, S.H.; Lin, F. Lowest elevation of plant growth and soil characteristics in natural drawdown areas in the Jiangjin section of the Yangtze River. Wetlands 2018, 39, 381-391. [CrossRef]

5. Zhang, Z.Y.; Wan, C.Y.; Zheng, Z.W.; Hu, L.; Feng, K.; Chang, J.B.; Xie, P. Plant community characteristics and their responses to environmental factors in the water level fluctuation zone of the three gorges reservoir in China. Environ. Sci. Pollut. Res. 2013, 20, 7080-7091. [CrossRef] [PubMed]

6. $\quad$ Bhattacharjee, J.; Taylor, J.P., Jr.; Smith, L.M.; Haukos, D.A. Seedling competition between native cottonwood and exotic saltcedar: Implications for restoration. Biol. Invasions 2009, 11, 1777-1787. [CrossRef]

7. Stromberg, J.C.; Beauchamp, V.B.; Dixon, M.D.; Lite, S.J.; Paradzick, C. Importance of low-flow and high-flow characteristics to restoration of riparian vegetation along rivers in arid south-western United States. Freshw. Biol. 2007, 52, 651-679. [CrossRef]

8. Davis, C.A.; Bidwell, J.R.; Hickman, K.R. Effects of hydrological regimes on competitive interactions of Schoenoplectus fluviatilis and two co-occurring wetland plants. Aquat. Bot. 2009, 91, 267-272. [CrossRef]

9. Moore, J.E.; Franklin, S.B. Understanding the relative roles of disturbance and species interactions in shaping Mississippi River island plant communities. Community Ecol. 2011, 12, 108-116. [CrossRef]

10. Bertness, M.D.; Callaway, R. Positive interactions in communities. Trends Ecol. Evol. 1994, 9, 191-193. [CrossRef]

11. He, Q.; Bertness, M.D.; Altieri, A.H. Global shifts towards positive species interactions with increasing environmental stress. Ecol. Lett. 2013, 16, 695-706. [CrossRef] [PubMed]

12. Maestre, F.T.; Callaway, R.M.; Valladares, F.; Lortie, C.J. Refining the stress-gradient hypothesis for competition and facilitation in plant communities. J. Ecol. 2009, 97, 199-205. [CrossRef]

13. Hawkins, T.S.; Schiff, N.M.; Leininger, T.D.; Gardiner, E.S.; Devall, M.S.; Hamel, P.B.; Wilson, A.D.; Connor, K.F. Growth and intraspecific competitive abilities of the dioecious Lindera melissifolia (Lauraceae) in varied flooding regimes. J. Torrey Bot. Soc. 2009, 136, 90-101. [CrossRef]

14. Moore, J.E.; Franklin, S.B. Water stress interacts with early arrival to influence interspecific and intraspecific priority competition: A test using a greenhouse study. J. Veg. Sci. 2012, 23, 647-656. [CrossRef]

15. Puy, J.; Carmona, C.P.; Dvoáková, H.; Latzel, V.; de Bello, F. Diversity of parental environments increases phenotypic variation in Arabidopsis populations more than genetic diversity but similarly affects productivity. Ann. Bot. 2021, 127, 425-436. [CrossRef] [PubMed]

16. Zhang, Y.Y.; Latzel, V.; Fischer, M.; Bossdorf, O. Understanding the evolutionary potential of epigenetic variation: A comparison of heritable phenotypic variation in epiRILs, RILs, and natural ecotypes of Arabidopsis thaliana. Heredity 2018, 121, $257-265$. [CrossRef]

17. Albert, C.H. Intraspecific trait variability matters. J. Veg. Sci. 2015, 26, 7-8. [CrossRef]

18. Messier, J.; McGill, B.J.; Lechowicz, M.J. How do traits vary across ecological scales? A case for trait-based ecology. Ecol. Lett. 2010, 13, 838-848. [CrossRef]

19. Siefert, A.; Violle, C.; Chalmandrier, L.; Albert, C.H.; Taudiere, A.; Fajardo, A.; Aarssen, L.W.; Baraloto, C.; Carlucci, M.B.; Cianciaruso, M.V.; et al. A global meta-analysis of the relative extent of intraspecific trait variation in plant communities. Ecol. Lett. 2015, 18, 1406-1419. [CrossRef] [PubMed]

20. Su, X.L.; Zeng, B.; Huang, W.J.; Xu, S.J.; Lei, S.T. Effects of the Three Gorges Dam on preupland and preriparian drawdown zones vegetation in the upper watershed of the Yangtze River, P.R. China. Ecol. Eng. 2012, 44, 123-127. [CrossRef]

21. Wu, J.G.; Huang, J.H.; Han, X.G.; Gao, X.M.; He, F.L.; Jiang, M.X.; Jiang, Z.G.; Primack, R.B.; Shen, Z.H. The Three Gorges Dam: An ecological perspective. Front. Ecol. Environ. 2004, 2, 241-248. [CrossRef]

22. Fan, D.Y.; Xiong, G.M.; Zhang, A.Y.; Liu, X.; Xie, Z.Q.; Li, Z.J. Effect of water-lever regulation on species selection for ecological restoration practice in the water-level fluctuation zone of Three Gorges Reservoir. Chin. J. Plant Ecol. 2015, 39, 416-432.

23. Yuan, S.H.; Zeng, B.; Su, X.L.; Xu, J.P. Effect of water-level fluctuation discrepancy on the composition of different annuals in Three Gorges Reservoir drawdown zone. Acta Econ. Sin. 2014, 34, 6481-6488.

24. Ye, C.; Zhang, K.R.; Deng, Q.; Zhang, Q.F. Plant communities in relation to flooding and soil characteristics in the water level fluctuation zone of the Three Gorges Reservoir, China. Environ. Sci. Pollut. Res. 2013, 20, 1794-1802. [CrossRef] [PubMed]

25. Chen, F.Q.; Li, Y.; Qie, G.W.; Xu, W.N. The morphological responses and endurance of Polygonum hydropiper to flooding stress. J. Wuhan Bot. Res. 2008, 2, 142-146.

26. Lan, Z.C.; Chen, Y.S.; Li, L.; Li, F.; Jin, B.S.; Chen, J.K. Testing mechanisms underlying elevational patterns of lakeshore plant community assembly in Poyang Lake, China. J. Plant Ecol. 2018, 12, 438-447. [CrossRef]

27. Intergovermental Panel on Climate Change (IPCC). Climate Change 2014: Impacts, Adaptation, and Vulnerability. Part A: Global and Sectoral Aspects. Contribution of Working Group II to the Fifth Assessment Report of the Intergovernmental Panel on Climate Change; Field, C.B., Barros, V.R., DOkken, D.J., Mach, K.J., Mastrandrea, M.D., Bilir, T.E., Chatterjhee, M., Ebi, K.L., Estrada, Y.O., Genova, R.C., et al., Eds.; Cambridge University Press: Cambridge, UK, 2014; p. 1132. 
28. Malkinson, D.; Tielbörger, K. What does the stress-gradient hypothesis predict? Resolving the discrepancies. Oikos 2010, 119, 1546-1552. [CrossRef]

29. Pellissier, L.; Bråthen, K.A.; Pottier, J.; Randin, C.F.; Vittoz, P.; Dubuis, A.; Yoccoz, N.G.; Alm, T.; Zimmermann, N.E.; Guisan, A. Species distribution models reveal apparent competitive and facilitative effects of a dominant species on the distribution of tundra plants. Ecography 2010, 33, 1004-1014. [CrossRef]

30. Gross, N.; Liancourt, P.; Choler, P.; Suding, K.N.; Lavorel, S. Strain and vegetation effects on local limiting resources explain the outcomes of biotic interactions. Perspect. Plant Ecol. 2010, 12, 9-19. [CrossRef]

31. Soliveres, S.; Eldridge, D.J.; Maestre, F.T.; Bowker, M.A.; Tighe, M.; Escudero, A. Microhabitat amelioration and reduced competition among understorey plants as drivers of facilitation across environmental gradients: Towards a unifying framework. Perspect. Plant Ecol. 2011, 13, 247-258. [CrossRef]

32. Li, A.R. Flora of China; Science Press: Beijing, China, 1998; Volume 25.

33. Chen, X.S.; Li, Y.F.; Cai, Y.H.; Xie, Y.H.; Deng, Z.M.; Li, F.; Hou, Z.Y. Differential strategies to tolerate flooding in Polygonum hydropiper plants originating from low- and high-elevation habitats. Front. Plant Sci. 2019, 9, 1970. [CrossRef]

34. Maxwell, K.; Johnson, G.N. Chlorophyll fluorescence-A practical guide. J. Exp. Bot. 2000, 51, 659-668. [CrossRef] [PubMed]

35. Pinheiro, J.; Bates, D.; DebRoy, S.; Sarkar, D. Nlme: Linear and Nonlinear Mixed Effects Models. R package version 3.1-152. Available online: https:/ /CRAN.R-project.org/package=nlme (accessed on 20 February 2021).

36. R Core Team. R: A Language and Environment for Statistical Computing; R Foundation for Statistical Computing: Vienna, Austria, 2021.

37. Adler, P.B.; Smull, D.; Beard, K.H.; Choi, R.T.; Furniss, T.; Kulmatiski, A.; Meiners, J.M.; Tredennick, A.T.; Veblen, K.E. Competition and coexistence in plant communities: Intraspecific competition is stronger than interspecific competition. Ecol. Lett. 2018, 21, 1319-1329. [CrossRef] [PubMed]

38. Kula, A.A.R.; Hey, M.H.; Couture, J.J.; Townsend, P.A.; Dalgleish, H.J. Intraspecific competition reduces plant size and quality and damage severity increases defense responses in the herbaceous perennial, Asclepias syriaca. Plant Ecol. 2020, 221, 421-430. [CrossRef]

39. Zhou, J.; Zheng, L.D.; Pan, X.; Li, W.; Kang, X.M.; Li, J.; Ning, Y.; Zhang, M.X.; Cui, L.J. Hydrological conditions affect the interspecific interaction between two emergent wetland species. Front. Plant Sci. 2018, 8, 2253. [CrossRef]

40. Muench, A.; Elsey-Quirk, T. Competitive reversal between plant species is driven by species-specific tolerance to flooding stress and nutrient acquisition during early marsh succession. J. Appl. Ecol. 2019, 56, 2236-2247. [CrossRef]

41. Yue, M.F.; Shen, H.; Li, W.H.; Chen, J.F.; Ye, W.H.; Tian, X.S.; Yin, A.G.; Cheng, S.M. Waterlogging tolerance of Bidens pilosa translates to increased competitiveness compared to native Bidens biternata. Plant Soil 2019, 437, 301-311. [CrossRef]

42. Lysenko, E.A.; Klaus, A.A.; Pshybytko, N.L.; Kusnetsov, V.V. Cadmium accumulation in chloroplasts and its impact on chloroplastic processes in barley and maize. Photosynth. Res. 2015, 125, 291-303. [CrossRef]

43. García-Cervigón, A.I.; Gazol, A.; Sanz, V.; Camarero, J.J.; Olano, J.M. Intraspecific competition replaces interspecific facilitation as abiotic stress decreases: The shifting nature of plant-plant interactions. Perspect. Plant Ecol. 2013, 15, 226-236. [CrossRef]

44. Qiu, S.Y.; Liu, S.S.; Wei, S.J.; Cui, X.H.; Nie, M.; Huang, J.X.; He, Q.; Ju, R.T.; Li, B. Changes in multiple environmental factors additively enhance the dominance of an exotic plant with a novel trade-off pattern. J. Ecol. 2020, 108, 1989-1999. [CrossRef]

45. Ye, C.; Butler, O.M.; Chen, C.; Liu, W.; Du, M.; Zhang, Q. Shifts in characteristics of the plant-soil system associated with flooding and revegetation in the riparian zone of Three Gorges Reservoir, China. Geoderma 2020, 361, 114015. [CrossRef]

46. Wei, G.W.; Chen, Y.H.; Sun, X.S.; Matsubara, S.; Luo, F.L.; Yu, F.H. Elevation-dependent selection for plasticity in leaf and root traits of Polygonum hydropiper in response to flooding. Environ. Exp. Bot. 2021, 182, 104331. [CrossRef]

47. Wei, G.W.; Sun, X.S.; Chen, Y.H.; Luo, F.L.; Yu, F.H. Growth and reproductive responses of Polygonum hydropiper populations to elevational difference associated with flooding. Glob. Ecol. Conserv. 2020, 23, e01156. [CrossRef]

48. Harpole, W.S.; Sullivan, L.L.; Lind, E.M.; Firn, J.; Adler, P.B.; Borer, E.T.; Chase, J.; Fay, P.A.; Hautier, Y.; Hillebrand, H.; et al. Addition of multiple limiting resources reduces grassland diversity. Nature 2016, 537, 93-96. [CrossRef]

49. Li, Y.; Kang, J.; Li, Z.; Korpelainen, H.; Li, C. Ecophysiological responses of two poplar species to intraspecific and interspecific competition under different nitrogen levels. J. Plant Ecol. 2020, 13, 693-703. [CrossRef]

50. Pedersen, O.; Perata, P.; Voesenek, L.A.C.J. Flooding and low oxygen responses in plants. Funct. Plant Biol. 2017, 44, iii-vi. [CrossRef]

51. Yamauchi, T.; Colmer, T.D.; Pedersen, O.; Nakazono, M. Regulation of root traits for internal aeration and tolerance to soil waterlogging-flooding stress. Plant Physiol. 2017, 176, 1118-1130. [CrossRef]

52. Polacik, K.A.; Maricle, B.R. Effects of flooding on photosynthesis and root respiration in saltcedar (Tamarix ramosissima), an invasive riparian shrub. Environ. Exp. Bot. 2013, 89, 19-27. [CrossRef]

53. van Veen, H.; Sasidharan, R. Shape shifting by amphibious plants in dynamic hydrological niches. New Phytol. 2019, 229, 79-84. [CrossRef] [PubMed]

54. Sher, A.A.; Marshall, D.L. Seedling competition between native Populus deltoides (Salicaceae) and exotic Tamarix ramosissima (Tamaricaceae) across water regimes and substrate types. Am. J. Bot. 2003, 90, 413-422. [CrossRef] 